\title{
Assessment of groundwater quality for irrigation: a case study from Bandalamottu lead mining area, Guntur District, Andhra Pradesh, South India
}

\author{
A. Nagaraju $\cdot$ K. Sunil Kumar $\cdot$ A. Thejaswi
}

Received: 18 October 2013/Accepted: 7 January 2014/Published online: 2 February 2014

(C) The Author(s) 2014. This article is published with open access at Springerlink.com

\begin{abstract}
Quality of water resources in the Bandalamottu area of Guntur District of Andhra Pradesh in South India is facing a serious challenge due to $\mathrm{Pb}$ mining. Therefore, 40 groundwater samples were collected from this area to assess their hydrogeochemistry and suitability for irrigation purposes. The groundwater samples were analyzed for distribution of chemical elements $\mathrm{Ca}^{2+}, \mathrm{Mg}^{2+}, \mathrm{Na}^{+}, \mathrm{K}^{+}$, $\mathrm{HCO}_{3}{ }^{-}, \mathrm{CO}_{3}{ }^{2-}, \mathrm{F}^{-}, \mathrm{Cl}^{-}$, and $\mathrm{SO}_{4}{ }^{2-}$. It also includes $\mathrm{pH}$, electrical conductivity, total hardness, non-carbonate hardness and total alkalinity. The parameters, such as sodium absorption ratio (SAR), adjusted SAR, sodium percentage, potential salinity, residual sodium carbonate, non-carbonate hardness, Kelly's ratio, magnesium ratio, permeability index, indices of base exchange (IBE) and Gibbs ratio were also calculated. The major hydrochemical facieses were $\mathrm{Ca}-\mathrm{HCO}_{3}, \mathrm{Ca}-\mathrm{Na}-\mathrm{HCO}_{3}$ and $\mathrm{Ca}-\mathrm{Mg}-\mathrm{Cl}$ types. The result of saturation index calculated by Visual MINTEQ software combined with Gibbs diagram and IBE findings indicate that, dolomite and calcite dissolution and reverse ion exchange can be a major process controlling the water chemistry in the study area. The results also showed that the salinity ( $85 \%, \mathrm{C} 3$ class) and alkalinity due to high concentration of $\mathrm{HCO}_{3}{ }^{-}$and $\mathrm{CO}_{3}{ }^{-}$and low Ca:Mg molar ratio $(97.5 \%,<1)$, are the major problems with water for irrigation usage. As a result, the quality of the groundwater is not suitable for sustainable crop production and soil health without appropriate remediation.
\end{abstract}

A. Nagaraju $(\bowtie) \cdot$ K. Sunil Kumar

Department of Geology, Sri Venkateswara University,

Tirupati 517 502, India

e-mail: arveti@yahoo.com

A. Thejaswi

Environmental Sciences, School of Distance Education, Kakatiya University, Warangal 506 009, India
Keywords Groundwater quality - Hydrogeochemistry · Irrigation · Salinity hazard · Alkalinity hazard . Bandalamottu area $\cdot$ South India

\section{Introduction}

India is endowed with abundant mineral resources which have contributed immensely to the national wealth with associated socio-economic benefits. Mineral resources are an important source of wealth for a nation, but before they are harnessed, they have to pass through the stages of exploration, mining, and processing (Adekoya 2003). Anthropogenic activities such as mining and smelting of metal ores have increased the occurrence of heavy metal contamination at the Earth's surface. Abandoned mines have been observed to be major sources of metals into the environment. Mining activities have a serious environmental impact on soils and water streams by generating millions of tons of sulfide-rich tailings (Banks et al. 1997; Younger 1997; Passariello et al. 2002; Younger and Robins 2002; Younger et al. 2002; Romano et al. 2003; Kovács et al. 2006; Bhattacharya et al. 2006). Sulfide ore tailings disposals result in the pollution of surface and groundwaters owing to uncontrolled discharge, i.e., removing from mining work (Kelly 1988). Mine tailings pose a special problem not only because these comprise the bulk of the generated waste from mining, but also due to the characteristically high metal concentrations (David 2002).

The activity such as metal mining release large amount of tailing and waste containing heavy metals which pose severe threat to water sources, agricultural soils and food crops (Jung 2001, 2008; Suresh et al. 2007; Aremua et al. 2010; Gutiérrez-Ginés et al. 2010; Tordoff et al. 2010). The natural occurrence of copper, zinc and lead at

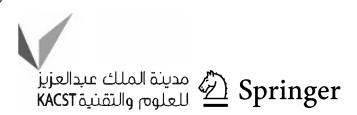


Bandalamottu and its commercial exploration potentially threatens local groundwater resources due to the leachate from the waste. Waste is commonly disposed on the earth's surface in rock dumps and spoil piles, and the barren remains of processing are contained in tailings. Mine waste can generate elevated levels of sulfate, metals and acidity. Unless mine waste sites are protected from oxidation and metal release, these sites represent a source of serious contamination to groundwater and aquatic systems for potentially hundreds to thousands of years (Marqués et al. 2001; Witkowski et al. 2003).

Water quality analysis is one of the most important aspects in groundwater studies. The hydrochemical study reveals quality of water that is suitable for drinking, agriculture and industrial purposes. Chemical analysis forms the basis of interpretation of the quality of water in relation to source, geology, climate, and use. Water being an excellent solvent, it is important to know the geochemistry of dissolved constituents and methods of reporting analytical data. The normal groundwater have typically neutral to slightly alkaline $\mathrm{pH}$ dominated by base cations $\left(\mathrm{Ca}^{2+}\right.$, $\mathrm{Mg}^{2+}, \mathrm{Na}^{+}$) and bicarbonate (Frengstad and Banks 2000). Groundwater is often defined as water occurring within the subsurface geological environment. Mine water is thus merely a type of groundwater, subject to the same geochemical processes as "normal" groundwater. We should start, however, by examining, in outline, some of the processes which give all groundwaters (including mine water) their characteristic chemical signatures.

The natural chemistry of the groundwater is largely controlled by the dissolution of the geologic materials through which the water flows. Contaminants enter groundwater from sources at the ground surface through chemical weathering soil leaching, decaying vegetation, etc. These dominant processes depend on the geological and geochemical conditions, as well as the chemical and biological characteristics of the contaminant. It is stated that the chemical composition of groundwater is affected by several diverse factors like topography, rock and soil compositions, rainfall pattern and temperature in the region, soil microbial diversity, land use pattern and several other anthropogenic processes, such as excess groundwater extraction for various applications, construction of storage reservoirs and canals, etc. (Handa 1974). The fate of chemical constituents in the groundwater is determined by their reactivity and migration capacity from the soil.

The inhabitants at Bandalamottu depend on the groundwater resources for drinking and agriculture. This study represents an initial effort to characterize the extent and nature of contamination in groundwater, as it potentially relates to the lead mining and processing. Surprisingly little attention has been given to this issue until recently.

\section{Geology}

The Bandalamottu base metal belt (Lat. $16^{\circ} 13^{\prime} 15^{2} \mathrm{~N}$ : Long $79^{\circ} 39^{\prime} 47^{2} \mathrm{E}$ ), is located in Vinukonda Taluk of Guntur District in the northeastern part of the Cuddapah Basin and constitutes one of the prominent base metal deposits in India. About 30 copper-lead-zinc occurrences are localized within this belt, with Bandalamottu, Nallakonda and Dhukonda constituting the main deposits. The present study represents the water quality studies related to Bandalamottu-Agnigundala mineralized belt and is included in the Survey of India Toposheet No. 56 P/12.

Earlier workers have studied on geology and genesis of the ore deposit (Ziauddin and Sharma 1968; Krishna Rao and Dhanu Raju 1974; Narayanaswami et al. 1977; Sivadas et al. 1985). In Bandalamottu block, the rock types are dolomite, cherty dolomite, phyllite with magnetite and chlorite. The zones of mineralization are confined mainly to the upper dolostone and dolomitic limestone, which crop out along the southern flank of the Bandalamottu hill, striking ENE-WSW and dipping $20^{\circ}-35^{\circ} \mathrm{WNW}$. The dolostone bed is the thickest in the middle and thins down on either end. It is interbedded with cherty dolostone, sandstone and calcareous sandstone, belonging to the Cumbum formation of Nallamalai Group of the Cuddapah Super group. Galena is the important ore mineral in this block while pyrite and sphalerite are next in abundance. The important minerals occurring in this belt are $\mathrm{Pb}, \mathrm{Zn}$ and $\mathrm{Cu}$.

The biotite-schists and amphibolites of metamorphic origin are the oldest rocks in this area and they belong to the archaeans. In addition, granites and dolerite dykes are also found. The Bairankonda formation, represented by grey, fine-grained, hard and compact sandstones with intercalated shale/slate units, except at a few places, directly overlies the granitic basement. The Cumbum formation is an argillaceous unit comprising shale, slaty-shale, slate and phyllite interbedded with fine to medium and coarse sandstone and dolostone/dolomitic limestone at various levels. The $\mathrm{Pb}-\mathrm{Zn}$ mineralized dolostone is rather restricted in occurrence as beds of varying thickness within the chlorite phyllite. The formations are folded, faulted and disturbed. Ore mineralization is concordant with bedding, though, in detail it occurs as lodes composed of veins, fracture-fillings and disseminations.

Topography, climate and soils

The general elevation of the area is $130-160 \mathrm{~m}$ above the sea level with hills and ridges rising from 300 to $600 \mathrm{~m}$ above the mean sea level. Climate of the area is tropical with hot summer and mild winter. The maximum temperature during summer is $45{ }^{\circ} \mathrm{C}$ and the minimum temperature will be 
$16{ }^{\circ} \mathrm{C}$. The average annual rainfall is $850 \mathrm{~mm}$. The plains are almost wholly covered with red soils and mixed soils containing black loam, sand and clay in varying amounts. They often contain boulders, cobbles, and pebbles of quartzite and vein quartz. Ferruginous laterite is found to cap some hills; calcareous kankar is also present in the soil in fairly large amounts. The streams are covered by shallow alluvium composed of boulders, cobbles, pebbles, gravels, sand, silt, and clay in varying amounts.

\section{Materials and methods}

The present study elucidates the chemical criteria of groundwater and the sample locations in the study are depicted in Fig. 1. It is therefore essential to conduct field and laboratory investigations to characterize, understand and interpret observed anomalies in groundwater in the regional context. In this area, 40 samples of groundwater were collected to study the chemical quality of water present in the region. To know the suitability of water for irrigation, chemical parameters like $\mathrm{pH}$, electrical conductivity (EC), $\mathrm{Ca}^{2+}, \mathrm{Mg}^{2+}, \mathrm{Na}^{+}, \mathrm{K}^{+}, \mathrm{Cl}^{-}, \mathrm{HCO}_{3}^{-}$, $\mathrm{CO}_{3}{ }^{2-}, \mathrm{SO}_{4}{ }^{2-}, \mathrm{F}^{-}$and various chemical index such as total dissolved solids (TDS), total hardness (TH), non-carbonate hardness $(\mathrm{NCH})$, total alkalinity (TA), sodium absorption ratio (SAR), adjusted SAR (adj.SAR), sodium percentage (SP), residual sodium carbonate (RSC), permeability index (PI), indices of exchange (IBE), Kelly's ratio and magnesium ratio were analyzed by adopting the standard procedures of water analysis. Saturation index (SI) values for mineral species were calculated using the Visual MINTEQ version 3.00 (Gustafsson 2012). The techniques and methods followed for collection, preservation, analysis and interpretation are those given by Hem (1985), Raghunath (1987), Karanth (1989), APHA (2005) and Todd and Mays (2005). The data are presented in Table 1.

\section{Results and discussion}

Water quality evaluation for irrigation purpose

The major ion chemistry of groundwater from Bandalamottu area were statistically analyzed and the results summarized by minimum, maximum, mean in Table 1. Suitability of the groundwater for irrigation purpose was discussed by the following basic criteria.
Fig. 1 Map of the study area with water sample locations

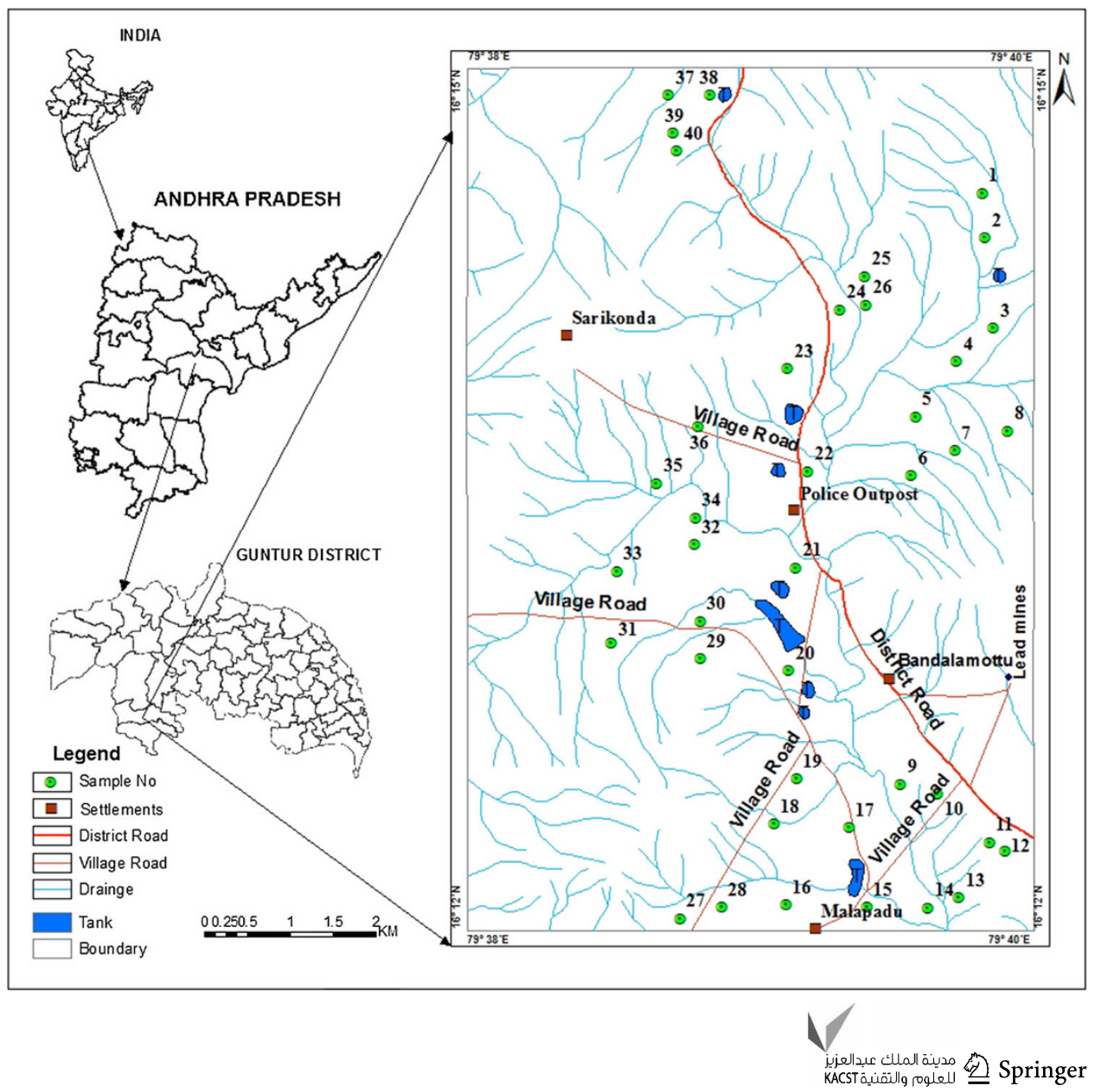


Table 1 Minimum, maximum and average values of different constituents of water samples of Bandalamottu area

\begin{tabular}{|c|c|c|c|c|}
\hline S. no & Constituents & Min & $\operatorname{Max}$ & Average \\
\hline 1 & Calcium $\left(\mathrm{Ca}^{2+}\right)(\mathrm{ppm})$ & 11.0 & 84.0 & 32.9 \\
\hline 2 & Magnesium $\left(\mathrm{Mg}^{2+}\right)(\mathrm{ppm})$ & 7.0 & 108.0 & 43.6 \\
\hline 3 & Sodium $\left(\mathrm{Na}^{+}\right)$(ppm) & 31.5 & 252.0 & 110.9 \\
\hline 4 & Potassium $\left(\mathrm{K}^{+}\right)(\mathrm{ppm})$ & 2.0 & 96.0 & 15.8 \\
\hline 5 & Bicarbonate $\left(\mathrm{HCO}_{3}^{-}\right)(\mathrm{ppm})$ & 144.0 & 598.0 & 368.9 \\
\hline 6 & Carbonate $\left(\mathrm{CO}_{3}{ }^{2-}\right)(\mathrm{ppm})$ & 6.0 & 49.0 & 15.2 \\
\hline 7 & Sulfate $\left(\mathrm{SO}_{4}{ }^{2-}\right)(\mathrm{ppm})$ & 76.0 & 475.0 & 151.6 \\
\hline 8 & Chloride $\left(\mathrm{Cl}^{-}\right)(\mathrm{ppm})$ & 17.0 & 276.0 & 94.9 \\
\hline 9 & Fluorine $\left(\mathrm{F}^{-}\right)(\mathrm{ppm})$ & 0.6 & 3.3 & 2.0 \\
\hline 10 & $\mathrm{pH}$ & 7.0 & 7.7 & 7.4 \\
\hline 11 & Specific conductance $\left(\mu \mathrm{mhoscm}^{-1}\right)$ & 415.0 & $1,475.0$ & $1,057.5$ \\
\hline 12 & Total dissolved solids (ppm) & 246.0 & 916.0 & 661.5 \\
\hline 13 & Hardness as $\mathrm{CaCO}_{3}(\mathrm{ppm})$ & 124.0 & 512.0 & 274.0 \\
\hline 14 & Non-carbonate hardness as $\mathrm{CaCO}_{3}(\mathrm{NCH})(\mathrm{ppm})$ & -388.0 & 235.2 & -64.7 \\
\hline 15 & Alkalinity as $\mathrm{CaCO}_{3}(\mathrm{ppm})$ & 156.0 & 582.0 & 339.7 \\
\hline 16 & Sodium adsorption ratio (SAR) & 1.1 & 8.0 & 3.3 \\
\hline 17 & Adjusted SAR (Adj.SAR) & 2.1 & 18.6 & 7.3 \\
\hline 18 & Sodium Percentage (SP) $(\%)$ & 21.6 & 77.4 & 49.2 \\
\hline 19 & Potential salinity (PS) $\left(\mathrm{meql}^{-1}\right)$ & 1.5 & 8.6 & 4.2 \\
\hline 20 & Residual sodium carbonate (RSC) $\left(\mathrm{meql}^{-1}\right)$ & -4.7 & 7.8 & 1.3 \\
\hline 21 & Permeability index (PI) $(\%)$ & 42.1 & 109.3 & 73.1 \\
\hline 22 & Kelly's ratio & 0.27 & 3.05 & 1.15 \\
\hline 23 & Indices of base exchange (IBE) CaI1 & -4.4 & 0.3 & -1.1 \\
\hline 24 & Indices of base exchange (IBE) CaI2 & -0.56 & 0.27 & -0.25 \\
\hline 25 & Gibbs ratio I & 0.12 & 0.61 & 0.3 \\
\hline 26 & Gibbs ratio II & 0.38 & 0.94 & 0.73 \\
\hline 27 & Calcium to magnesium molar ratio & 0.2 & 2.0 & 0.5 \\
\hline 28 & Magnesium ratio $(\%)$ & 33.4 & 82.4 & 67.7 \\
\hline
\end{tabular}

\section{Water quality based on absolute amount of ions}

Among the cations, the concentrations of $\mathrm{Ca}^{2+}, \mathrm{Mg}^{2+}, \mathrm{Na}^{+}$ and $\mathrm{K}^{+}$ions ranged from 11 to 84,7 to $108,31.5$ to 252 and 2 to $96 \mathrm{ppm}$ with a mean value of $32.9,43.6,110.9$ and $15.8 \mathrm{ppm}$, respectively (Table 1). The maximum permissible limit of $\mathrm{Ca}^{2+}, \mathrm{Mg}^{2+}, \mathrm{Na}^{+}$and $\mathrm{K}^{+}$in irrigation water is $80,35,200$ and $30 \mathrm{ppm}$, respectively (Duncan et al. 2000 and Sharifi and Safari Sinegani 2012). On the basis of these permissible limits, 57,7 and $15 \%$ of the water samples are unsuitable for irrigation usage with respect to $\mathrm{Mg}^{2+}, \mathrm{Na}^{+}$and $\mathrm{K}^{+}$, respectively. Among the anions, the concentrations of $\mathrm{HCO}_{3}{ }^{-}, \mathrm{CO}_{3}{ }^{2-}, \mathrm{Cl}^{-}$, $\mathrm{SO}_{4}{ }^{2-}$ and $\mathrm{F}^{-}$ions lie in between 144 and 598, 6 and 49, 17 and 276,76 and $475,0.6$ and $3.3 \mathrm{ppm}$ with a mean value of $368.9,15.2,94.9,151.6$ and $2.0 \mathrm{ppm}$, respectively (Table 1). The maximum permissible limit of $\mathrm{HCO}_{3}{ }^{-}, \mathrm{CO}_{3}{ }^{2-}, \mathrm{Cl}^{-}$, $\mathrm{SO}_{4}{ }^{2-}$ and $\mathrm{F}^{-}$in irrigation water is $250,15,250,180$ and 10 ppm, respectively (McKee and Wolf 1963; Duncan et al. 2000; Sharifi and Safari Sinegani 2012). According to the grading standards $85,37,2.5$ and $17.5 \%$ of the water samples are unsuitable for irrigation usage with respect to $\mathrm{HCO}_{3}{ }^{-}$,
$\mathrm{CO}_{3}{ }^{2-}, \mathrm{Cl}^{-}$and $\mathrm{SO}_{4}{ }^{2-}$, respectively. It should be noted that the absolute concentration of ions by itself is not enough for assessing suitability of ions for irrigation usage. Thus, the effects of interactions among the ions should also be considered for this issue. For this reason, to accurate estimate of the hazards of the ions in the water samples, in the next sections, we adopted the methods that include the interactions.

$p H$

$\mathrm{pH}$ is a term used universally to express the intensity of the acid or alkaline condition of a solution. From the Table 1, it is observed that the $\mathrm{pH}$ values of the water samples ranged from 7.0 to 7.7 with a mean value of 7.4 in the study area. All the water samples fall in the safe limit of $\mathrm{pH}$ standard (6-8.5) for irrigation purpose (Ayers and Westcot 1985).

\section{Salinity hazard}

Determination of salinity hazard is very important in irrigation water, as high salt content renders the soil saline. 
This also affects the salt intake capacity of the plants through the roots. Electrical conductivity (EC) is a measure of water capacity to convey electric current. It signifies the amount of total dissolved salts (TDS). Thus, in the present study, the salinity hazard was evaluated by EC and TDS, their amounts varied from 415 to $1475 \mu \mathrm{mhoscm}^{-1}$ and 246-916 ppm with an average value of 1,057.5 $\mu \mathrm{mhoscm}^{-1}$ and $661.5 \mathrm{ppm}$, respectively. Based on the classification of TDS as suggested by USSL (1954), most of the water samples $(85 \%)$ are classified as moderate water category. According to the EC grading standards as suggested by Wilcox (1955), most of the water samples $(85 \%)$ are classified as permissible water category. Therefore, the continuation use of this moderate saline water for irrigation in the long term may increase the salinity hazard in the soils of the studied area.

\section{Potential salinity}

Doneen (1964) explained that the suitability of water for irrigation is not dependent on soluble salts. Because, the low solubility salts precipitate in the soil and accumulate with each successive irrigation, the concentration of highly soluble salts increase the soil salinity. Potential salinity is defined as the chloride concentration plus half of the sulfate concentration as showed below:

P.S $=\mathrm{Cl}^{-}+1 / 2 \mathrm{SO}_{4}^{2-}$

All ionic concentration is in meql ${ }^{-1}$.

The potential salinity of the water samples range from 1.5 to $8.6 \mathrm{meql}^{-1}$ with an average of $4.2 \mathrm{meql}^{-1}$. It suggests that the potential salinity in the groundwater of the studied area nearly is high, thus, making the water unsuitable for irrigation usage. High values of potential salinity in the area can be ascribed to high sulfate content derived from the lead mining, the major mineral mined in the studied area.

\section{Total alkalinity}

In the natural environment, carbonate alkalinity tends to make up most of the total alkalinity. Other common natural components that can contribute to alkalinity include borate, hydroxide, phosphate, silicate, nitrate, dissolved ammonia, the conjugate bases of some organic acids and sulfide. Alkalinity is important because it buffers $\mathrm{pH}$ changes that occur naturally during photosynthetic cycles, water exchanges, etc. From the Table 1, it is clear that the alkalinity ranges from 156.0 to 582.0 with an average value of $339.7 \mathrm{ppm}$ as $\mathrm{CaCO}_{3}$. The high amount of alkalinity in the Bandalamottu area water samples can be due to the presence of calcareous rocks, such as dolomite in this area.

\section{Sodium hazard}

The excessive sodium content in water sample reduces the permeability, and hence, the available water for the plant is reduced. Sodium replacing adsorbed calcium and magnesium is a hazard, as it causes damage to the soil structure resulting in compact and impervious soil (Arveti et al. 2011). Excess absorption of sodium can cause sodium toxicity in sensitive plants, causing marginal leaf burn on older foliage and possibly defoliation and water containing excessive amount of sodium may immobilize other nutrient ions particularly calcium, magnesium and potassium, which can result in deficiencies of these elements in plants (NWQMS 2000; Kelly 1951; Domenico and Schwartz 1990; Todd and Mays 2005; Sharifi and Safari Sinegani 2012).

Irrigation water is classified on the basis of SAR (WHO 1989). Hence, the assessment of sodium hazard is necessary while considering the suitability for irrigation. One of the most important criteria in determining sodium hazard is sodium adsorption ratio (SAR) (Todd and Mays 2005). It is an easily measured property that gives information on the comparative concentrations of $\mathrm{Na}^{+}, \mathrm{Ca}^{2+}$, and $\mathrm{Mg}^{2+}$ in soil solutions. Sodium adsorption ratio is computed as:

$\mathrm{SAR}=\frac{\mathrm{Na}^{+}}{\sqrt{\left(\mathrm{Ca}^{2+}+\mathrm{Mg}^{2+}\right) / 2}}$

All ionic concentration is in meql ${ }^{-1}$.

As shown in Table 1, the SAR values of the groundwater samples varied from 1.1 to 8.0 with an average value of 3.3. The SAR values of the water samples of the studied area to be $<10$ and are classified as excellent for irrigation (Richards 1954).

Kelly (1940) and Wilcox (1958) have also determined the hazardous effect of sodium on water quality for irrigation usage in terms of Kelly's ratio (KR) and sodium percentage (SP), respectively. Kelly's ratio and SP are computed as:

$$
\begin{aligned}
& \left\{\text { Kelly's ratio }=\mathrm{Na}^{+} /\left(\mathrm{Ca}^{2+}+\mathrm{Mg}^{2+}\right)\right\} \\
& \mathrm{SP}=\frac{\left(\mathrm{Na}^{+}+\mathrm{K}^{+}\right)}{\left(\mathrm{Ca}^{2+}+\mathrm{Mg}^{2+}+\mathrm{Na}^{+}+\mathrm{K}^{+}\right)} \times 100
\end{aligned}
$$

All ionic concentrations are in meql ${ }^{-1}$.

A Kelly's ratio of more than one indicates excessive sodium in water. Therefore, water with a Kelly's ratio less than one are suitable for irrigation, while those with a ratio more than one are unsuitable. From the Table 1, it can be suggested that the Kelly's ratio varies from 0.27 to 3.05 with an average value of 1.15 . In the present study, $42 \%$ of the water samples are unsuitable for irrigation with more than one of Kelly's ratio. 
From the Table 1, it is observed that the sodium percentage values of the study area samples vary from 21.6 to $77.4 \%$ with an average value $49.2 \%$. Sodium percentage is plotted against conductivity, which is designated as Wilcox diagram and is illustrated in Fig. 2. It is clear that water samples fall into the categories of "excellent to good" (15\%), "good to permissible" (52.5\%), and "permissible to doubtful" (32.5\%).

\section{Carbonate and bicarbonates hazard}

Water containing excessive amount of $\mathrm{HCO}_{3}$ and $\mathrm{CO}_{3}$, react with $\mathrm{Ca}^{2+}$ and $\mathrm{Mg}^{2+}$ in soil solution and will precipitate them as calcite and magnesite. This will allow sodium adsorbed to dominate onto the clay surfaces, to enhanced exchangeable sodium percentage (ESP) of soil, which increases sodium hazard and its related problems such as reducing soil permeability, soil aeration, high $\mathrm{pH}$, inhibit root penetration, etc. (Bohn et al. 1985; Domenico and Schwartz 1990; Todd and Mays 2005). Thus, some of the researchers have attempted to present equations to show the effects of interactions among $\mathrm{Ca}^{2+}, \mathrm{Mg}^{2+}, \mathrm{Na}^{+}$,

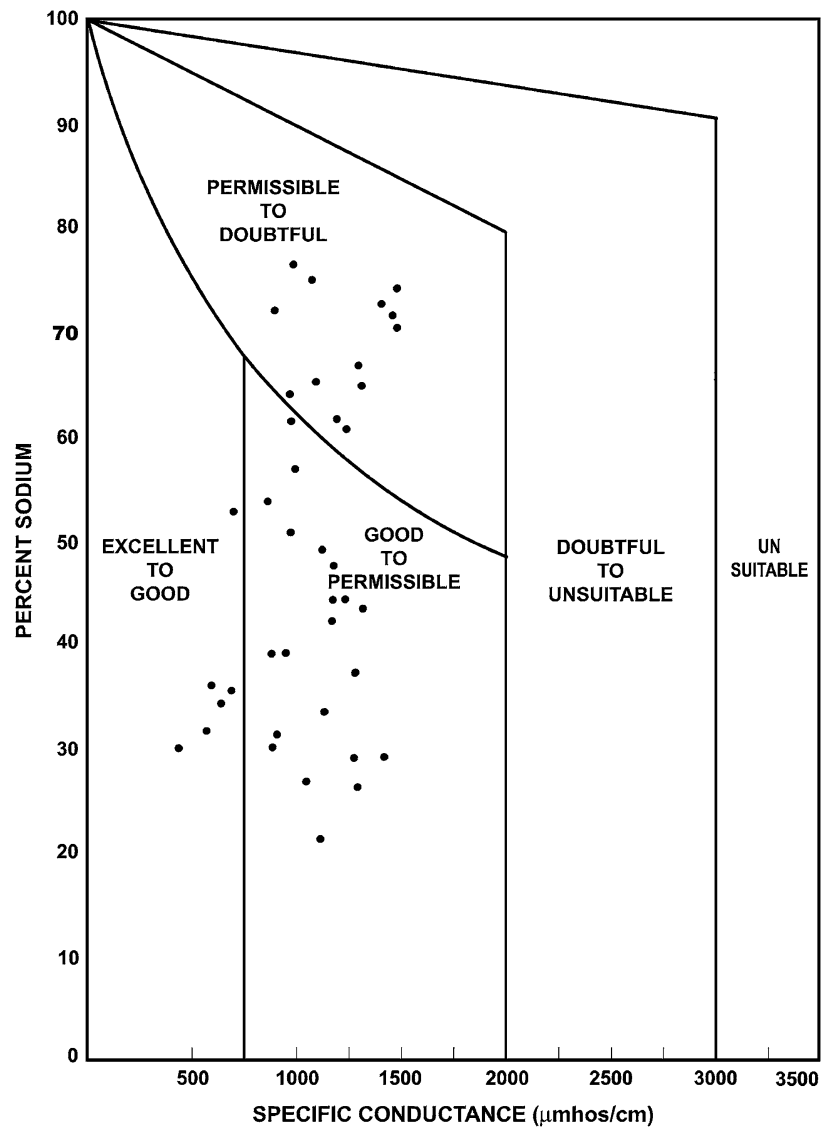

Fig. 2 The quality of water in relation to electrical conductivity and percent sodium (Wilcox diagram)
$\mathrm{HCO}_{3}{ }^{-}$and $\mathrm{CO}_{3}{ }^{2-}$ on water quality for irrigation purpose. They are as follows:

$\mathrm{RSC}=\left(\mathrm{HCO}_{3}^{-}+\mathrm{CO}_{3}^{-}\right)-\left(\mathrm{Ca}^{2+}+\mathrm{Mg}^{+}\right)$

P.I. $=\frac{\mathrm{Na}^{+}+\sqrt{\mathrm{HCO}_{3}^{-}}}{\left(\mathrm{Ca}^{2+}+\mathrm{Mg}^{2+}+\mathrm{Na}^{+}\right)} \times 100$

Adjusted sodium adsorption ratio (adj.SAR) $=$ SAR $\left[1+\left(8.4 \mathrm{pH}_{\mathrm{c}}\right)\right]($ Ayers and Westcot 1985)

$\mathrm{pHc}=\left(\mathrm{pK}_{2}-\mathrm{pK}_{\mathrm{c}}\right)+\mathrm{p}(\mathrm{Ca}+\mathrm{Mg})+\mathrm{p}($ Alk $)$

where

$\mathrm{pK}_{2}$ Negative logarithm of the second disassociation constant for carbonic acid

$\mathrm{pK}_{\mathrm{c}} \quad$ Solubility constant for calcite

$\mathrm{p} \quad$ Negative logarithm of ion concentration

All ionic concentration is in meql ${ }^{-1}$.

From the Table 1, it can be interpreted that the groundwaters in the study area shows RSC values of -4.7 to 7.8 with an average value of $1.3 \mathrm{meql}^{-1}$. Based on the US Salinity Laboratory (1954), over 16 samples have values $<1.25 \mathrm{meql}^{-1}$ and are safe for irrigation; 11 samples have RSC values between 1.25 and $2.5 \mathrm{meql}^{-1}$ are marginal in quality and 13 samples have RSC values $>2.5 \mathrm{meql}^{-1}$ and are unsuitable for irrigation. The water with high RSC has high $\mathrm{pH}$ and land irrigated by such water becomes infertile owing to deposition of sodium carbonate as indicated by the black color of the soil (Eaton 1950).

Water can be classified as Class I, Class II and Class III orders with regard to permeability index (PI). Class I and Class II waters are categorized as good for irrigation with $75 \%$ or more of maximum permeability. Class III waters are unsuitable with $25 \%$ of maximum permeability (Donnen 1964). From the Table 1, it can be demarcated that the PI values vary from 42.1 to 109.3 with an average of 73.1. Nearly $50 \%$ water samples fall into the Class I Category of Donnen's chart and are categorized as good for irrigation.

Although RSC and PI are useful parameters for assessing of carbonate and bicarbonates hazard, adj.SAR is basically used for assessment of alkalinity hazard in irrigation water, amount of which was 2.1-18.6 with a mean value of 7.3 (Table 1). The result showed that the concern due to sodium hazard of the water became more emphatic because in all water samples adj.SAR is higher than SAR. Based on Ayers and Tanji (1981) classification, $15 \%$ of samples have adj.SAR values $<3$ and are safe for irrigation; $57.5 \%$ of samples have adj.SAR values between 3 and 9 are increasing problem for irrigation and remained samples $(27.5 \%)$ have adj.SAR values $>9$ and are severe problems for irrigation. 
In general, the obtained results from the calculation of RSC, PI and adj.SAR suggest that there is tendency for calcium and magnesium to precipitate with carbonate and bicarbonate as calcite and magnesite in the soils irrigated by the water, resulting in an increased sodium hazard and its related problems in the area.

\section{Salinity and alkalinity hazard class}

According to US Salinity Laboratory's diagram (Richards $1954)$ in Fig. 3, salinity and alkalinity hazard class of water samples were C3-S1 (70 \%), C3-S2 (15\%) and $\mathrm{C} 2-\mathrm{S} 1(15 \%)$. The result shows that a majority of the groundwaters possess high salinity with low sodium (C3S1). Läuchli and Epstein (1990) have pointed out that salinity can have effect on growth and development of plants in different ways, such as osmotic effects, specificion toxicity and/or nutritional disorders. Thus, the excessive amount of salts can be one of the major problems with water used for irrigation in this area and the water cannot be used for irrigation with most crops without special circumstances for salinity control such as leaching requirement or cropping of salt-tolerant plants. In this study about $15 \%$ of the water samples fall in high salinity and medium alkalinity hazard class (C3-S2), with continuous use of the such water samples in the long term will increase both salinity and alkalinity hazard in the soil.

\section{Magnesium hazard}

Generally, calcium and magnesium maintain a state of equilibrium in most waters. More magnesium in water adversely affects the crop yield. As the rocks of the study area comprise dolomites, most water possess more magnesium than calcium. For this reason, in this study magnesium hazard was evaluated by two following methods including "magnesium ratio" and "calcium to magnesium molar ratio". From the Table 1, it is seen that the magnesium ratio $\left\{\mathrm{Mg}^{2+}\right.$ ratio $\left.=\left[\mathrm{Mg}^{2+} /\left(\mathrm{Ca}^{2+}+\mathrm{Mg}^{2+}\right)\right] \times 100\right\}$ has varied from 33.4 to 82.40 with an average value of 67.7. In this study, nearly all of the water samples has $\mathrm{Mg}$ ratio more than $50 \%$, which adversely affect the crop yield as turn the soils more alkaline (Paliwal 1972). The high values of observed 'magnesium ratio' are due to the influence of dolomite in these areas. The result support that $\mathrm{Ca}: \mathrm{Mg}$ molar ratio nearly in all of the surveyed water samples was $<1$ (range 0.2-2.0, mean 0.5). Jalali (2008) and Joshi et al. (2009) have pointed out that water with a $\mathrm{Ca}: \mathrm{Mg}$ molar ratio $<1$, results in an increased $\mathrm{SAR}$ value, which adversely affects soil structure and crop yield as the soils become more saline.

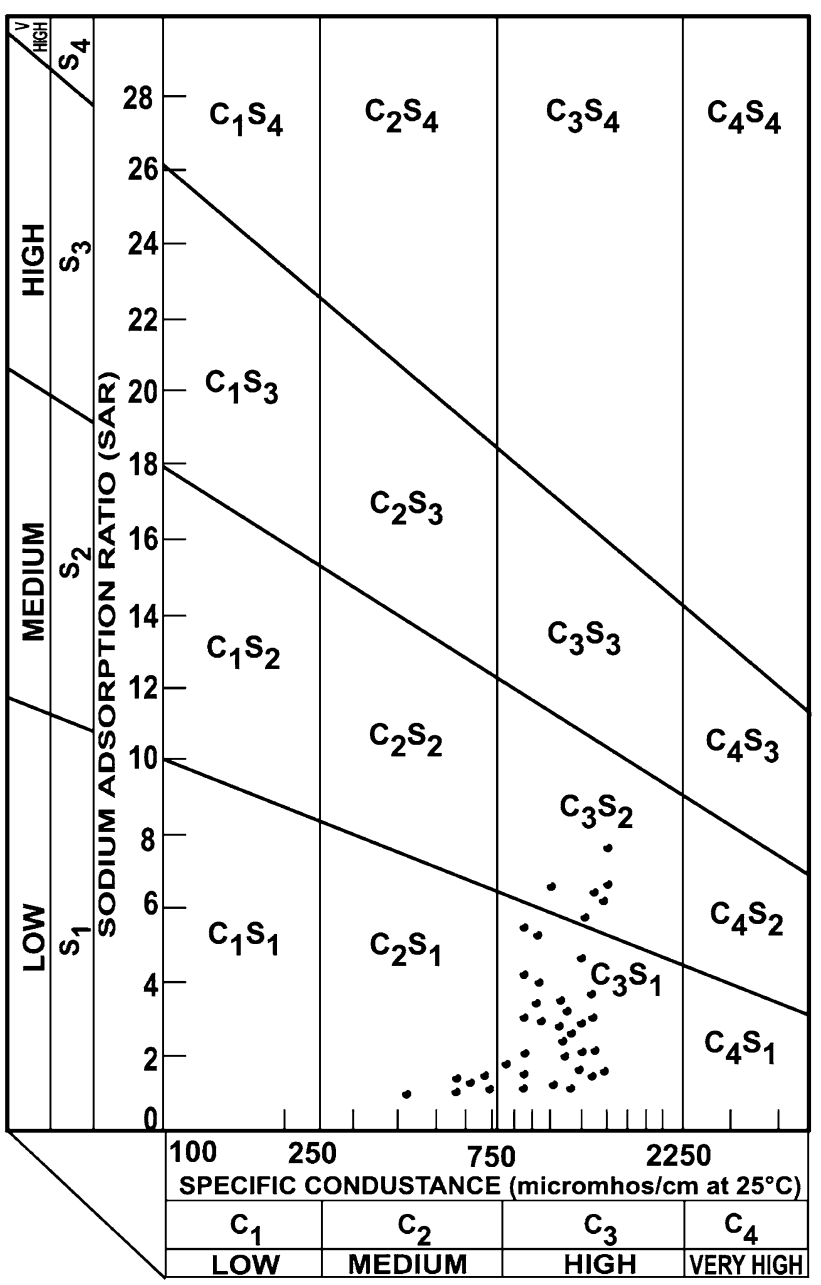

Fig. 3 The quality of water in relation to salinity and sodium hazard (after US Salinity Laboratory 1954)

\section{Total hardness}

Hard water is water that has high content of calcium and magnesium ions, and sometimes other dissolved compounds such as iron. Calcium usually enters the water as either calcium carbonate $\left(\mathrm{CaCO}_{3}\right)$, in the form of limestone and chalk, or calcium sulfate $\left(\mathrm{CaSO}_{4}\right)$, in the form of other mineral deposits. The predominant source of magnesium is dolomite $\left(\mathrm{CaMg}\left(\mathrm{CO}_{3}\right)_{2}\right)$. Piper's diagram confirms that all the groundwaters in the study area are characterized as alkaline earth's $(\mathrm{Ca}+\mathrm{Mg})$ exceeds alkalies $(\mathrm{Na}+\mathrm{K})$ and all the groundwaters in the study area described as weak acids $\left(\mathrm{CO}_{3}+\mathrm{HCO}_{3}\right)$ exceed strong acids $\left(\mathrm{SO}_{4}+\mathrm{Cl}+\mathrm{F}\right)$. In the present study, area hardness of water samples varied from 124.0 to 512.0 with a mean value of $274.0 \mathrm{ppm}$ as $\mathrm{CaCO}_{3}$. Based on Sawyer et al. (2003) classification the water are classified as moderately hard (5\%), hard (55\%) and very hard (40\%). In general, water with hardness more than $200 \mathrm{ppm}$ as $\mathrm{CaCO}_{3}$ will lead to scale deposits in the piping system (Van der Aa 
2003). Thus, the result suggests that most of the water samples $(72 \%)$ can be problematic for plumbing of irrigation systems.

\section{Non-carbonate hardness $(\mathrm{NCH})$}

Hardness of water relates to the reaction with soap, since $\mathrm{Ca}$ and $\mathrm{Mg}$ ions precipitate soap. Hardness is expressed as ppm of $\mathrm{CaCO}_{3}$. If the hardness as $\mathrm{CaCO}_{3}$ exceeds the difference between the alkalinity as $\mathrm{CaCO}_{3}$ and hardness as $\mathrm{CaCO}_{3}$, it is termed as non-carbonate hardness. It is also called permanent hardness. From the Table 1, it can be delineated that the $\mathrm{NCH}$ values ranged from -388.0 to 235.2 with an average of -64.7 .

\section{Geochemical classification and hydrogeochemical facies}

In order to understand water composition and chemical relationship between dissolved ions, the concept of hydrochemical facies of the investigated area are used in Pipers (1953) trilinear diagram for graphical analysis (Fig. 4). This diagram reveals similarities and differences among water samples (Todd 1980). The facies mapping approach applied to the present study shows dominance of alkaline earth over strong acids (Fig. 4) and samples fall in the $\mathrm{Ca}-$
$\mathrm{HCO}_{3}$ type $(35 \%), \mathrm{Ca}-\mathrm{Na}-\mathrm{HCO}_{3}$ type $(37.5 \%)$ and $\mathrm{Ca}-$ $\mathrm{Mg}-\mathrm{Cl}$ type $(20 \%)$. Remaining samples fall in the field of $\mathrm{Na}-\mathrm{Cl}$ type. The results suggest that mixed cation- $\mathrm{HCO}_{3}$ is the dominant hydrochemical facies for the surveyed groundwaters. The principal water type depicts rock-water interaction involving the dissolution of carbonates by weathered zone above the underlying rocks. There is a tendency in the groundwater to carbonate mineral saturation by dissolving dolomite and calcite in the soil and bedrock in the recharge area as:

$$
\begin{aligned}
& \mathrm{CaMg}\left(\mathrm{CO}_{3}\right) \text { (Dolomite) }+2 \mathrm{H}^{+} \\
& \quad \leftrightarrow \mathrm{Ca}^{2+}+\mathrm{Mg}^{2+}+2 \mathrm{HCO}_{3}^{-} \\
& \mathrm{CaCO}_{3}(\text { Calcite })+\mathrm{H}^{+} \leftrightarrow \mathrm{Ca}^{2+}+\mathrm{HCO}_{3}^{-} .
\end{aligned}
$$

These results are supported by that the basement minerals in this area are mainly carbonates and saturation indices of 55,30 and $10 \%$ of the water samples, respectively, for dolomite, calcite and aragonite were positive.

\section{The origin of solutes}

In this section, the origin of solutes and the process that generated the observed water compositions in the water has been assayed by the following methods:
Fig. 4 Piper diagram for representing the analysis of ground water

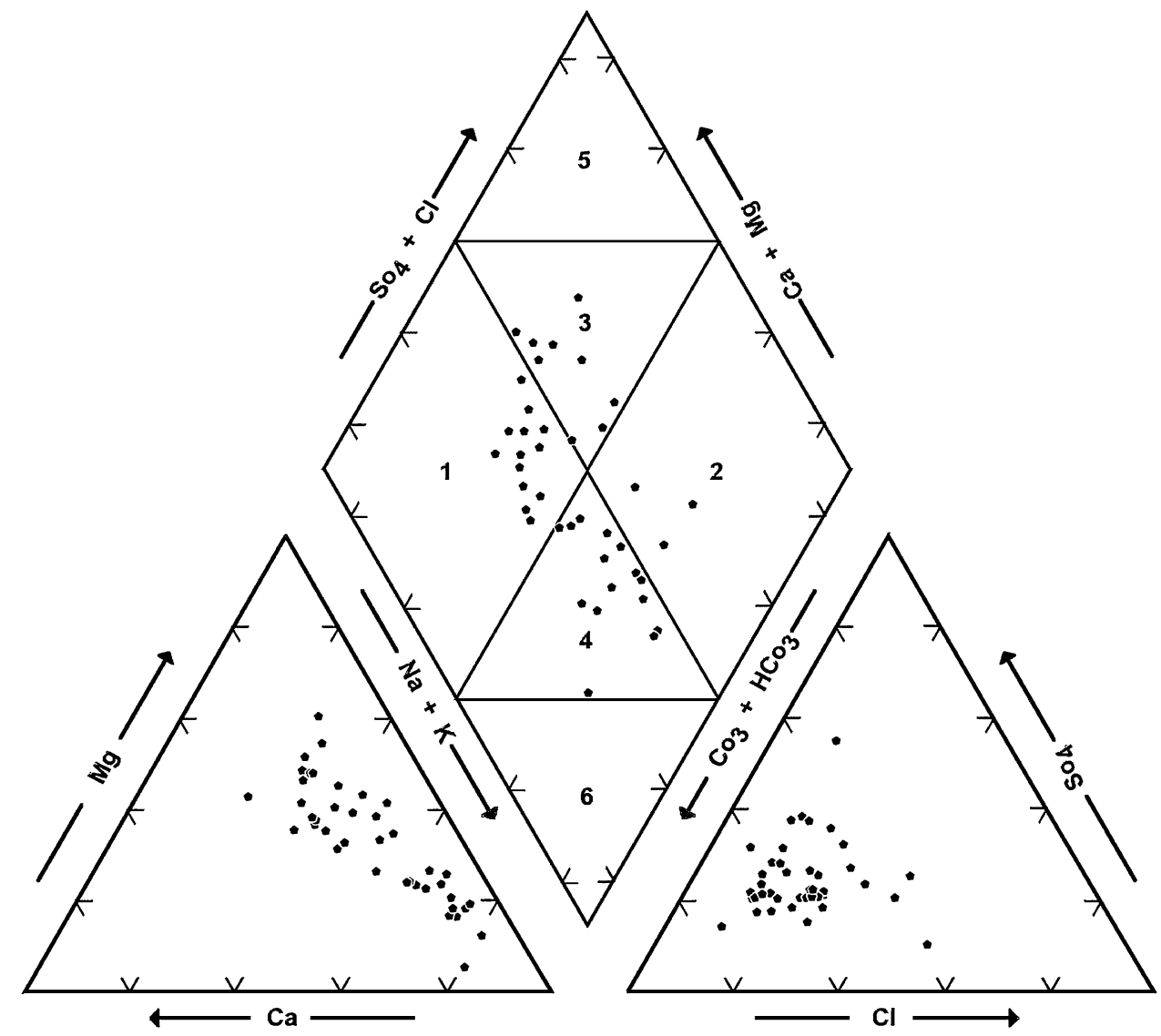


1. Hydrogeochemical modeling

2. Indices of base exchange (IBE)

3. Gibbs ratio.

I. Hydrogeochemical modeling To evaluate the potential chemical reactions in the groundwater, the saturation indices (SI) of the water with respect to mineral phases were calculated using geochemical model Visual MINTEQ version 3.00 (Gustafsson 2012). The model has an extensive thermodynamic database that allows for the study ion speciation, solubility, equilibrium of solid and dissolved phases of minerals in an aqueous solution (Gustafsson 2012). This program is the windows version of MINTEQ that was originally developed by the US EPA (Allison et al. 1991). Summary statistics of the modeling are presented in Table 2. The saturation index (SI) quantitatively indicates about the dissolution and precipitation reactions occurring in the groundwater. The negative, zero and positive values of the index, respectively, indicate under-saturation, equilibrium and oversaturation of water with respect to dissolved minerals (Appelo and Postma 1996; Drever 1997).

As shown in Table 2, $55 \%$ of the all water samples were oversaturated with respect to dolomite (SI ranged

Table 2 Summary statistics of mineral saturation index (SI) of Bandalamottu groundwater calculated by Visual MINTEQ

\begin{tabular}{rlrrrl}
\hline S & Mineral saturation & Min & Max & Mean & $\begin{array}{l}\text { Std. } \\
\text { deviation }\end{array}$ \\
\hline 1 & Andex (SI) & -0.87 & 0.21 & -0.35 & 0.29 \\
2 & Artinite & -7.15 & -5.28 & -6.28 & 0.59 \\
3 & Brucite & -6.10 & -4.73 & -5.44 & 0.39 \\
4 & Calcite & -0.73 & 0.36 & -0.21 & 0.29 \\
5 & Dolomite (disordered) & -1.35 & 0.44 & -0.49 & 0.49 \\
6 & Dolomite (ordered) & -0.80 & 1.03 & 0.06 & 0.50 \\
7 & Epsomite & -4.80 & -3.30 & -4.05 & 0.27 \\
8 & Fluorite & -2.00 & -0.51 & -1.10 & 0.35 \\
9 & Gypsum & -2.44 & -1.26 & -1.91 & 0.25 \\
10 & Halite & -7.90 & -6.00 & -6.65 & 0.41 \\
11 & Hydromagnesite & -15.14 & -10.80 & -12.94 & 1.30 \\
12 & Lime & -22.37 & -20.50 & -21.39 & 0.50 \\
13 & Magnesite & -1.34 & -0.50 & -0.90 & 0.24 \\
14 & Mirabilite & -7.90 & -6.00 & -6.90 & 0.50 \\
15 & Natron & -10.00 & -7.70 & -8.83 & 0.54 \\
16 & Nesquehonite & -4.13 & -3.27 & -3.67 & 0.24 \\
17 & Periclase & -10.59 & -9.30 & -9.93 & 0.40 \\
18 & Portlandite & -12.40 & -10.50 & -11.40 & 0.47 \\
19 & Thenardite & -9.33 & -7.40 & -8.30 & 0.50 \\
20 & Thermonatrite & -11.94 & -9.65 & -10.78 & 0.54 \\
21 & Vaterite & -1.29 & -0.21 & -0.78 & 0.28 \\
\hline & & & & & \\
\hline & & & & &
\end{tabular}

Positive values indicate saturation, and negative ones indicate undersaturation
-0.08 to 1.03 , mean 0.06 ), $30 \%$ with respect to calcite (SI ranged -0.73 to 0.36 , mean -0.21 ) and $10 \%$ with respect to Aragonite (SI ranged -0.87 to 0.25 , mean -0.35 ), and all water samples were under-saturated with respect to sulfur-bearing minerals (gypsum, epsomite, mirabilite and thenardite). Thus, precipitation is expected for calcite and dolomite and dissolution is expected for gypsum, epsomite, mirabilite and thenardite. These findings indicate that dissolution of dolomite and calcite can be the main mechanism responsible for the chemical composition of the groundwaters in the studied area.

II. Indices of base exchange (IBE) Control of the dissolution of undesirable constituents in water is impossible during the subsurface run off, but it is essential to know the changes undergone by the water during its movement (Pojasek 1977; Johnson 1979). The ion exchange between the groundwater and its host environment during residence or travel are well understood by studying the chloro-alkaline indices. To know the direction of exchange during the path of groundwater through the aquifer, Schoeller (1967, 1977) suggested two chloro-alkaline indices $\mathrm{CaI}_{1}$ and $\mathrm{CaI}_{2}$ to indicate the exchange of ions between groundwater and its host environment. This is positive when there is an exchange of $\mathrm{Na}^{+}$and $\mathrm{K}^{+}$from the water with $\mathrm{Mg}^{2+}$ and $\mathrm{Ca}^{2+}$ of the rocks, and is negative when there is an exchange of $\mathrm{Mg}^{2+}$ and $\mathrm{Ca}^{2+}$ of the water with $\mathrm{Na}^{+}$and $\mathrm{K}^{+}$ of the rocks.

From the Table 1, it can be put forth that the $\mathrm{CaI}_{1}$ values range from -4.4 to 0.3 with a mean of -1.1 and $\mathrm{CaI}_{2}$ values vary from -0.56 to 0.27 with a mean of -0.25 . From these values, it can be interpreted that most of the samples $(95 \%)$ in the studied area fall into negative zones. They indicate that the exchange of $\mathrm{Mg}^{2+}$ and $\mathrm{Ca}^{2+}$ of the water with $\mathrm{Na}$ and $\mathrm{K}$ in its host environment is prevalent in the studied area. The result suggests that cation exchangeable can also be one of the mechanisms responsible for the chemical composition of the groundwaters in the studied area.

III. Gibbs ratio Gibbs (1970) proposed a diagram to understand the relationship of the chemical components of water from their respective aquifer lithologies. Viswanathaiah et al. (1978) emphasized the mechanisms that control the chemistry of groundwater in Karnataka. Ramesam and Barua (1973) have also carried out similar research work in the northwestern regions of India. The Gibbs diagram illustrates three distinct fields, namely precipitation dominance, evaporation dominance and rock dominance areas that are shown in Gibbs diagram (Fig. 5).

The Gibbs ratios are calculated with the formulae given below: 
Gibbs ratio I (for Anion) $=\mathrm{Cl}^{-} /\left(\mathrm{Cl}^{-}+\mathrm{HCO}_{3}^{-}\right)$

Gibbs ratio II (for Cation) $=\left(\mathrm{Na}^{+}+\mathrm{K}^{+}\right) /\left(\mathrm{Na}^{+}+\mathrm{K}^{+}\right.$

$$
\left.+\mathrm{Ca}^{2+}\right)
$$

All ionic concentrations are in meq ${ }^{-1}$.

Gibbs ratios for the study area samples are plotted against their respective total dissolved solids as shown in Fig. 5 to know whether the groundwater chemistry is due to rock dominance, evaporation dominance or precipitation dominance. In the present study, Gibbs ratio I values in the present study vary from 0.12 to 0.61 with a average value

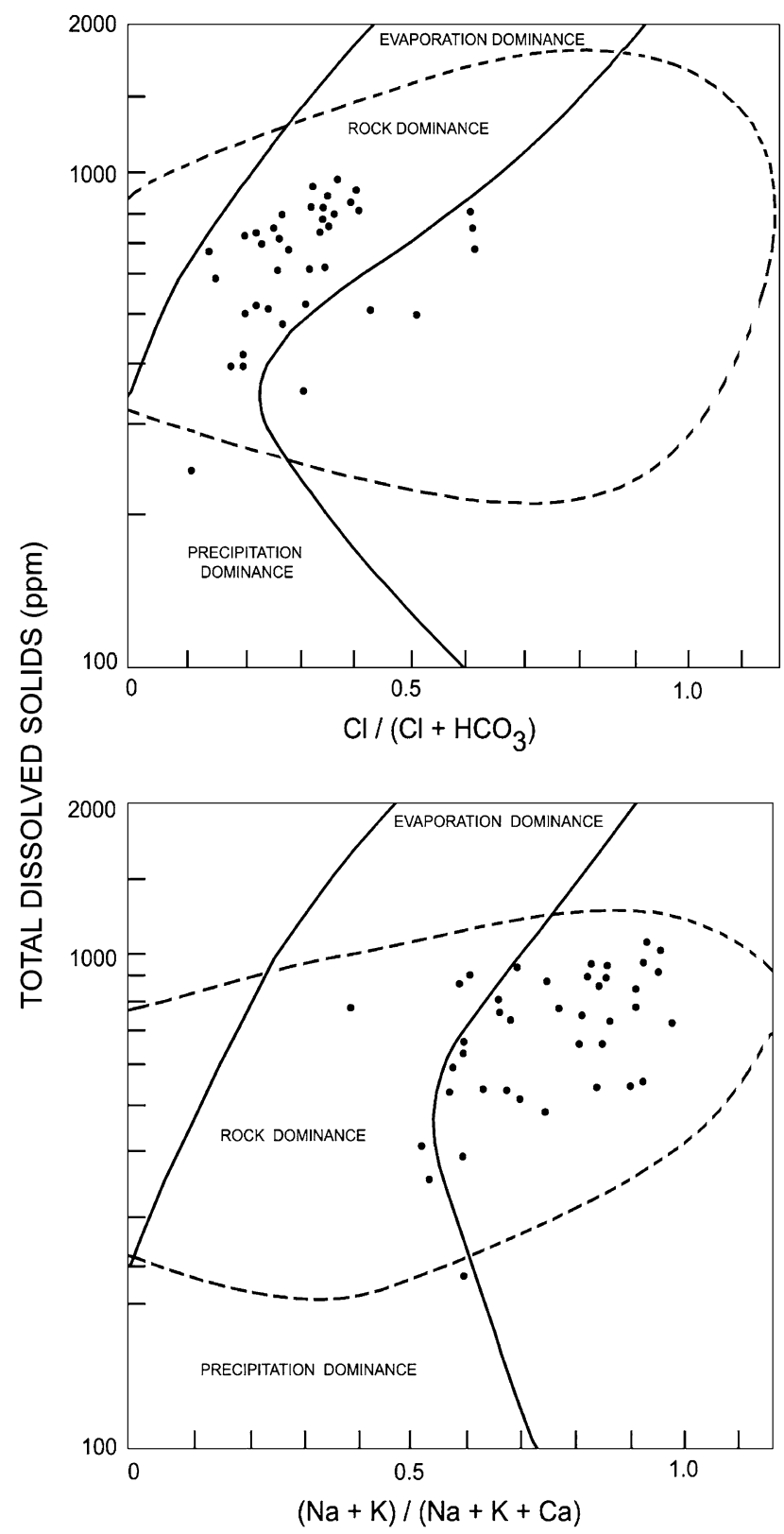

Fig. 5 Mechanism controlling the quality of ground water (after Gibb's 1970) of 0.30 and Gibbs ratio II values vary from 0.38 to 0.94 with a average value of 0.73 . From Fig. 5, it can be elucidated that in the study area the samples fall into the rock dominance area, indicating the influence of rocks on the groundwater in the aquifers.

\section{Conclusion}

The groundwater resources in the Bandalamottu region were evaluated for their chemical composition and suitability for irrigation. The abundance of the major ions is as follows: $\mathrm{Mg}^{2+}>\mathrm{Ca}^{2+}>\mathrm{Na}^{+}>\mathrm{K}^{+}$and $\mathrm{HCO}_{3}{ }^{-}>\mathrm{Cl}^{-}>$ $\mathrm{SO}_{4}{ }^{2-}>\mathrm{CO}_{3}{ }^{2-}>\mathrm{F}^{-}$. Dolomite is the predominant source of the huge amounts of magnesium found in the groundwater. The major hydrochemical facieses were $\mathrm{Ca}-\mathrm{HCO}_{3}$, $\mathrm{Ca}-\mathrm{Na}-\mathrm{HCO}_{3}$ and $\mathrm{Ca}-\mathrm{Mg}-\mathrm{Cl}$ types. The saturation index (SI) of minerals calculated by Visual MINTEQ software showed that $55 \%$ of all water samples were oversaturated with respect to dolomite, $30 \%$ with respect to calcite and $10 \%$ with respect to Aragonite, and all water samples were under-saturated with respect to sulfur-bearing minerals. The result of SI together with Gibbs diagram and indices of base exchange (IBE) findings indicate that dissolution of dolomite and calcite and reverse ion exchange can be the main mechanisms responsible for the chemical composition of the groundwater in the studied area. The results also showed that the surveyed groundwater for irrigation purposes have a high salinity hazard ( $85 \%, \mathrm{C} 3$ class), high alkalinity hazard due to high concentration of $\mathrm{HCO}_{3}{ }^{-}$and $\mathrm{CO}_{3}{ }^{2-}$ and low $\mathrm{Ca}: \mathrm{Mg}$ molar ratio $(97.5 \%,<1)$, slight basic in nature and are very hard. Based on the results of this study, the quality of the groundwater is not suitable for irrigation and continuation of their use in the long term may increases the salinity and alkalinity problems in the soils.

Acknowledgments The author Prof. Nagaraju likes to acknowledge the University Grants Commission (UGC), New Delhi, for supporting this major research project (Project No. 39-140/2010). The authors thank Dr. Z. Sharifi, Department of Soil Science, College of Agriculture, University of Kurdistan, Sanandaj, Iran for helping in the treatment of statistical analysis of the chemical quality of the data.

Open Access This article is distributed under the terms of the Creative Commons Attribution License which permits any use, distribution, and reproduction in any medium, provided the original author(s) and the source are credited.

\section{References}

Adekoya JA (2003) Environmental effect of solid minerals mining. J Physical Sci Kenya, 625-640

Allison GD, Brown DS, Novo-Gradac KJ (1991) MINTEQA2/ PRODEFA2, a geochemical assessment model for 
environmental systems: Version 3.0 Users manual. US Environmental Protection Agency, Athens (EPA/600/3-91/021)

APHA (2005) Standard methods for the examination of water and wastewater, 21st edn. American Public Health Association, Washington

Appelo CAJ, Postma D (1996) Geochemistry, groundwater and pollution. Balkema, Rotterdam, p 536

Aremua MO, Sangarib DU, Adeyeye EI, Ishalekua YY (2010) Metal concentration in soils, ponds and associated food crops in azara derelict baryte mining area in Nigeria. EJEAFChe 9:10-18

Arveti N, Sarma MRS, Aitkenhead-Peterson JA, Sunil K (2011) Fluoride incidence in groundwater: a case study from Talupula, Andhra Pradesh, India. Environ Monit Asses 172:427-443

Ayers RS, Tanji KK (1981) Agronomic aspects of crop irrigation with wastewater. Proc Spec Conf Water Forum 81(1):578-586

Ayers RS, Westcot DW (1985) Water quality for agriculture. FAO irrigation and drainage paper, 29(Rev. 1):1-144

Banks D, Younger PL, Arnesen RT, Iversen ER, Banks SB (1997) Mine-water chemistry: the good, the bad and the ugly. Env Geol 32:157-174

Bhattacharya A, Routh J, Jacks G, Bhattacharya P, Mörth M (2006) Environmental assessment of abandoned mine tailings in Adak, Vasterbotten district (northern Sweden). Appl Geochem 21:1760-1780

Bohn HL, Mcneal BL, O'connor GA (1985) Soil Chemistry. Wiley Interscience, New York, p 341

David CP (2002) Heavy metal concentrations in marine sediments impacted by a mine-tailings spill. Marinduque Island Philipp Environ Geol 42:955-965

Domenico PA, Schwartz FW (1990) Physical and chemical hydrogeology. John Wiley and Sons, New York

Doneen LD (1964) Water quality for agriculture. Department of Irrigation, University of California, Davis. 48

Drever JI (1997) The geochemistry of natural waters, 3rd edn. Prentice Hall, New Jersey, p 436

Duncan RR, Carrow RN, Huck M (2000) Under standing water quality and guidelines to management (an overview of challenges for water usage on golf courses for the 21 century). USGA Green Section Record, 14-24

Eaton FM (1950) Significance of carbonates in irrigated waters. Soil Sci 69:127-128

Frengstad B, Banks D (2000) Evolution of HighpH Na-HCO3 Groundwaters in Anorthosites: Silicate Weathering or Cation Exchange? In: Sililo et al. (Eds.): "Groundwater: Past Achievements and Future Challenges", Proc. XXXIInd Congress of the International Association of Hydrogeologists. Cape Town, South Africa. Balkema, Rotterdam, 493-498

Gibbs RJ (1970) Mechanisms controlling world water chemistry. Science 170:1081-1090

Gustafsson GP (2012) Visual MINTEQ, ver 3.00. Royal Institute of Technology, Stockholm, Sweden, Department of Land and Water Resources Engineering. http://hem.bredband.net/b108693S. AllisonJD,BrownDS,Novo-GradacKJ(1991) MINTEQA2

Gutiérrez-Ginés MJ, Pastor J, Hernández AJ (2010) Effect of heavy metals from mine soils on Avena Sativa 1 and education strategies. Fresenius Environ Bull 19:2083-2087

Handa BK (1974) Methods of collection and analysis of water samples and interpretation of water analysis data. Govt. of India, 365

Hem JD (1985) Study and interpretation of chemical characteristics of natural water. U.S.G.S. Water Supply Paper. 3rd Edn. No. 2254, 263

Jalali M (2008) Effect of sodium and magnesium on kinetics of potassium release in some calcareous soils of western Iran. Geoderma 145:207-215

Johnson CC (1979) Land application of waste-an accident waiting to happen. Groundwater 17:69-72
Joshi DM, Kumar A, Agrawal N (2009) Assessment of the irrigation water quality of River Ganga in Haridwar District India. J Chem 2(2):285-292

Jung MC (2001) Heavy metal contamination of soils and waters in and around the Imcheon Au-Ag mine, Korea. Appl Geochem $16: 1369-1375$

Jung MC (2008) Heavy metal contamination in soils and factors affecting metal uptake by plants in the vicinity of a Korean $\mathrm{Cu}$ W mine. Sensors 8:2413-2423

Karanth KR (1989) Hydrogeology. Tata McGraw-Hill Publ. Co. Ltd. New Delhi, 720

Kelly WP (1940) Permissible composition and concentration of irrigated waters. In: Proceedings of the A.S.C.F, 607

Kelly WP (1951) Alkali soils-their formation, properties and reclamation. Reinhold Publ, New York

Kelly M (1988) Mining and freshwater environment. Elsevier Applied Science, London, New York

Kovács E, Dubbin WE, Tamás J (2006) Influence of hydrology on heavy metal speciation and mobility in a $\mathrm{Pb}-\mathrm{Zn}$ mine tailing. Environ Pollut 141:310-320

Krishna Rao JSR, Dhanu Raju R (1974) Genesis of lead-copper ores in Agnigundala area, Andhra Pradesh. J Geol Soc India 15:239-245

Läuchli A, Epstein E (1990) Plant responses to saline and sodic conditions. In: Tanji KK (ed.) Agricultural salinity assessment and management. ASCE New York. ASCE manuals and reports on engineering practice No, 71:113-137

Marqués MJ, Martínez-Conde E, Rovira JV, Ordoñez S (2001) Heavy metals pollution of aquatic ecosystems in the vicinity of a recently closed underground lead-zinc mine (Basque Country, Spain). Environ Geol 40:1125-1137

McKee JE, Wolf HW (1963) Water quality criteria. The Resource Agency of California. 2nd Ed. State Water Quality Control Board. Public. No. 3A

Narayanaswami S, Sashikumar KT, Sivadas KM, Gopalakrishnan KP (1977) Lead copper deposits of Agnigundala, Guntur District, Andhra Pradesh. Geol Surv India Misc Publ 16:197-203

NWQMS (National Water Quality Management Strategy Paper) (2000) No. 4 Australian and New Zealand Guidelines for Fresh and Marine Water Quality, vol 3, Primary Industries-Rationale and Background Information (Irrigation and general water uses, stock drinking water, aquaculture and human consumers of aquatic foods), Agriculture and Resource Management Council of Australia and New Zealand

Paliwal KV (1972) Irrigation with saline water (p. 198) Monogram No. 2 (New series). IARI, New Delhi

Passariello B, Giuliano V, Quaresima S, Barbaro M, Caroli S, Forte G, Carelli G (2002) Evaluation of the environmental contamination at an abandoned mining site. Microchem J 73:245-250

Piper AM (1953) A graphic procedure in the geochemical interpretation of water analysis. USGS Groundwater Note, No. 12

Pojasek RB (1977) (Ed.) Drinking Water Quality Enhancement through Protection. Ann Arbor Publishers Inc., Ann Arbor, Michigan

Raghunath HM (1987) Groundwater. Wiley Eastern Limited, New Delhi. 563

Ramesam V, Barua SK (1973) Preliminary studies on the mechanisms of controlling salinity in the North Western arid regions of India. Indian Geohydrol 9:10-18

Richards LA (1954) (Ed.) Diagnosis and improvement of saline and alkali soils. USDA Hand book, No. 60, 160

Romano CG, Mayer KU, Jones DR, Ellerbroek DA, Blowes DW (2003) Effectiveness of various cover scenarios on the rate of sulfide oxidation of mine tailings. J Hydrol 271:171-187

Sawyer CN, McCarthy PL, Parkin GF (2003) Chemistry for environmental engineering and science. McGraw-Hill, New York, 5 Ed, 752

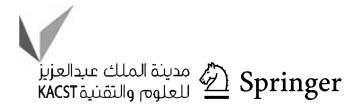


Schoeller H (1967) Qualitative evaluation of groundwater resources. In: Methods and techniques of groundwater investigation and development. Water Res. UNESCO, 33:44-52

Schoeller H (1977) Geochemistry of groundwater. In: Groundwater studies-an international guide for research and practice. UNESCO, Paris, 15:1-18

Sharifi Z, Safari Sinegani AA (2012) Arsenic and other irrigation water quality indicators of groundwater in an agricultural area of Qorveh Plain, Kurdistan, Iran. Am Eurasian J Agric Environ Sci 12(4):548-555

Sivadas KM, Sashikumar KT, Subba Rao N, Setti DN, Rajkumar ST, Sharma RK, Gopalakrishnan KP, Sagar AK (1985) Lead and copper deposits of Agnigundala Guntur district, Andhra Pradesh. Geol Surv India Misc Publ 13:65-72

Suresh S, Dinakar N, Prasad TNVKV, Nagajyothi PC, Damodharam T, Nagaraju A (2007) Effects of a barite mine on groundwater quality in Andhra Pradesh, India. Mine Water Environ 26:119-123

Todd DK (1980) Groundwater hydrology, 2nd edn. Wiley \& Sons, New York, p 535

Todd DK, Mays LW (2005) Groundwater hydrology. 3rd edn. Wiley, Hoboken, NJ, 656

Tordoff GM, Baker AJM, Willis AJ (2000) Current approaches to the revegetation and reclamation of metalliferous mine wastes. Chemosphere 41:219-228

U.S. Salinity Laboratory (1954) Diagnosis and improvement of saline and alkaline soils. U.S. Dept. of Agriculture. Hand Book, 60, 160

USSL (1954) Diagnosis and Improvement of Saline and Alkali Soils. USDA Hand Book, 60:147
Van der Aa NGFM (2003) Classification of mineral water types and comparison with drinking water standards. Environ Geol 44:554-563

Viswanathaiah MN, Sastri JCV, Rame Gowda B (1978) Mechanisms controlling the chemistry of groundwaters of Karnataka. Ind Miner 19:65-69

WHO (1989) Guidelines for the safe use of wastewater and excreta in agriculture and aquaculture: World Health Organization. 187

Wilcox LV (1955) Classification and use of Irrigation water. US Dept of Agriculture, Washington, Circular No. 969:19

Wilcox LV (1958) Determining the quality of irrigation water. Dept. of Agriculture, USA, p 6

Witkowski A, Motyka J, Wróbel J (2003) Assessment of potential risk of groundwater contamination in areas subjected to the intensive mining drainage. Case study from Poland-Olkusz $\mathrm{Zn}-\mathrm{Pb}$ ore mining region. 8th International Congress on Mine Water \& the Environment, Johannesburg, South Africa, 19-22, October 2003, 221-234

Younger PL (1997) The longevity of mine water pollution: a basis for decision-making. Sci Tot Env 194:457-466

Younger PL, Robins NS (2002) (Eds.) Mine water hydrogeology and geochemistry. Geological Society, London, Special Publication, 198:396

Younger PL, Banwart SA, Hedin RS (2002) Mine water: hydrology, pollution, remediation. Kluwer Academic Publishers, Dordrecht (ISBN 1-4020-0137-1), 464

Ziauddin M, Sharma RK (1968) Copper-lead deposits of Agnigundala, Guntur district, Andhra Pradesh. Geol Survey India Misc Publ 13:65-72 